\title{
EXCHANGE RATE VOLATILITY AND ITS IMPACT ON US EXPORTS TO EUROPEAN UNION
}

Marcellus Morris, Department of Economics and Business Analytics, University of New Haven, West Haven, U.S.A.

Raja Nag, Department of Finance, School of Management, New York Institute of Technology, Old Westbury, NY, U.S.A.

Kamal P. Upadhyaya, Department of Economics and Business Analytics, University of New Haven, West Haven, U.S.A.

\section{dx.doi.org/10.18374/JIBE-19-3.7}

\begin{abstract}
This paper estimates the effect of US dollar exchange rate volatility on the volume of US exports to the European Union using quarterly data from 1997 to 2018. For that a model is developed which includes domestic and foreign income, real effective exchange rate, and exchange rate volatility as explanatory variables and exports as the dependent variable. Before estimating the model, the time series properties of the data series are diagnosed, and an error correction model is developed. In addition to estimating the error correction model a simple OLS is also estimated. The results from both estimations indicate that the exchange rate volatility has a positive effect on US exports to the European Union.
\end{abstract}

Keywords: Exchange rate volatility, trade volume, United States, European Union 